\title{
Growth factors and the control of folliculogenesis
}

\author{
P. Monget and D. Monniaux \\ INRA, Station de Reproduction des Mammifères Domestiques, URA CNRS 1291, 37380 Nouzilly,
}

France

\begin{abstract}
There is increasing evidence that growth factors modulate folliculogenesis. However their precise role in the processes of follicular growth, differentiation and atresia is still unknown. Growth factors belong to complex systems, including all the factors structurally and functionally related, their receptor(s) and, in most cases, binding proteins or proteoglycans. In this review, the insulin-like growth factor (IGF) system is presented as a paradigm for the study of other growth factor systems in the ovary. IGFs are probably positive regulators of follicular development, as they enhance both proliferation and differentiation and amplify the action of gonadotrophins on follicular cells. In the ovaries of most mammals, there is little or no change in intrafollicular IGF concentrations during terminal follicular growth and atresia. By contrast, the concentrations of IGF-binding proteins $<40 \mathrm{kDa}$ (mainly IGFBP-2, -4 and -5 ) decrease markedly during terminal follicular growth, but increase in atretic follicles. These variations could result from both changes in expression of these IGFBPs by follicular cells and in local degradation by gonadotrophin-induced specific protease(s). Experiments in vitro showed that these IGFBPs, present in a soluble form in follicular fluid, could play an important role by sequestrating the IGFs and decreasing their bioavailability. More generally, biological actions of growth factors critically depend on their bioavailability in the vicinity of the cell, resulting from the concentrations of the factors themselves, their binding proteins and the ability of specific proteases to degrade binding proteins or to cleave latent forms of growth factors. These mechanisms and their control by gonadotrophins throughout follicular development have now to be investigated for the different growth factor systems.
\end{abstract}

\section{Introduction}

Follicular development involves important morphological and functional changes in thecal and granulosa cells (proliferation, steroidogenesis, gonadotrophin sensitivity) and in the oocyte (cytoplasmic and nuclear maturation). There is substantial evidence that gonadotrophins play a key role in controlling folliculogenesis. However, follicular development is also controlled by various other factors (steroids, growth factors) of endocrine and paracrine origin. In this review, attention will be directed towards the importance of growth factors in the control of folliculogenesis.

Growth factors are directly involved in regulation of cell proliferation and differentiation. Thereby, they probably play an essential role in all processes of morphogenesis, cell growth and differentiation, and maintenance of tissue homoeostasis. The different growth factors have been classed into separate families, based on their structure and biological activity; the epidermal growth factor (EGF) family, the fibroblast growth factor (FGF) family, the platelet-derived growth factor (PDGF) family, the insulin-like growth factor (IGF) family, the transforming growth factor $\beta$ (TGF- $\beta$ ) family and the haemopoietic growth factors (cytokines). Our knowledge of their exact role in folliculogenesis is still limited for two reasons. 
Table 1. Growth factors, receptors and binding compounds in four families of growth factors

\begin{tabular}{|c|c|c|c|}
\hline Family & Growth factors & Receptors & Binding compounds \\
\hline EGF & $\begin{array}{l}\text { EGF } \\
\text { TGF- } \alpha \\
\text { HBEGF } \\
\text { Amphiregulin }\end{array}$ & EGF receptor $\left(\begin{array}{c}c-e r b \\
B\end{array}\right)$ & $\begin{array}{l}\text { Heparin } \\
\text { HSPG }\end{array}$ \\
\hline FGF & $\begin{array}{l}\text { FGF-1 (acidic FGF, aFGF) } \\
\text { FGF-2 (basic FGF, bFGF) } \\
\text { FGF-3 (int-2) } \\
\text { FGF-4 (Hst-1/K-FGF) } \\
\text { FGF-5 } \\
\text { FGF-6 (Hst-2) } \\
\text { FGF-7 (keratinocyte growth factor) }\end{array}$ & $\begin{array}{l}\text { FGF receptor I }(f l g) \\
\text { FGF receptor } 2(b e k) \\
\text { FGF receptor } 3 \\
\text { FGF receptor } 4 \\
/ l g-2\end{array}$ & $\begin{array}{l}\text { Heparin } \\
\text { HSPG }^{a} \\
\alpha_{2}-\text { Macroglobulin }^{2}\end{array}$ \\
\hline TGF- $\beta$ & $\begin{array}{l}\text { TGF- } \beta 1 \\
\text { TGF- } \beta 2 \\
\text { TGF- } \beta 3 \\
\text { TGF- } \beta 5\end{array}$ & $\begin{array}{l}\text { Type I receptor } \\
\text { Type II receptor }\end{array}$ & $\begin{array}{l}\text { Latent TGF- } \beta \text { binding protein } \\
\text { Proteoglycans }{ }^{\mathrm{b}} \\
\text { Type IV collagen } \\
\text { Fibronectin } \\
\text { Thrombospondin } \\
\alpha_{2} \text {-Macroglobulin }\end{array}$ \\
\hline IGF & $\begin{array}{l}\text { IGF-I } \\
\text { IGF-II }\end{array}$ & $\begin{array}{l}\text { IGF-I receptor } \\
\text { IGF-II-M6P receptor }\end{array}$ & 6 Binding proteins (IGFBPs) \\
\hline
\end{tabular}

Other nomenclatures for factors are indicated in parentheses. The name of the proto-oncogenes, when they are known, are indicated in italics. EGF; epidermal growth factor; FGF: fibroblast growth factor; TGF: transforming growth factor; IGF: insulin-like growth factor; HBEGF: heparin-binding EGF-like growth factor; HSPG: heparan sulfate proteoglycans. "Particularly syndecan and betaglycan; "particularly betaglycan, endoglin and decorin.

First, growth factors are ubiquitous; they are secreted by various types of cell and act locally in a paracrine or autocrine way. Some of them, such as factors of the EGF and the PDGF families and various cytokines, are expressed in a transmembrane form and can activate receptors on adjacent cells, in a so-called juxtacrine way (Wong et al., 1989). In addition, a particular intracellular mode of action (intracrine action) was described for factors of the FGF family (Logan, 1990). However, growth factors can also act on target cells in an endocrine way, like hormones. This is of particular importance in the ovary, since proteins with molecular masses of less than $10^{3} \mathrm{kDa}$, and presumably growth factors, cross the basal membrane of the follicle (Shalgi et al., 1973). Consequently, intrafollicular growth factors may have both a local and an endocrine origin.

Second, growth factors belong to complex systems, including all the factors structurally and functionally related, their receptor(s), and, in most cases, binding proteins or proteoglycans. In this review, we will present some of the general features of these growth factor systems.

\section{Main Characteristics of Growth Factor Systems}

Each system of growth factors includes three different types of elements: the growth factors, their signalling receptors and binding proteins and proteoglycans (Table 1). Four factors are known in the EGF system, at least seven in the FGF system, four in the TGF- $\beta$ system (not including TGF- $\beta$-related peptides, such as activin, inhibin and the Müllerian inhibitory substance) and two in the IGF system.

Growth factors bind and activate specific signalling receptors. Only one tyrosine kinase receptor is known in the EGF system. In the FGF system, five different tyrosine kinase receptors have been described. Moreover, a number of variants of these receptors can be generated by alternative splicing of mRNAs (Turnbull and Gallagher, 1993). In the TGF- $\beta$ system, two different types of serine/threonine 
kinase receptors are known; interaction of both receptors is required to achieve cellular signalling. The same type I receptor binds either activin or TGF- $\beta$, depending on the presence of either the activin or TGF- $\beta$ type II receptor (Attisano et al., 1993). In this system, interactions between receptor types would control different cellular responses to TGF- $\beta$-like molecules. The IGF system is characterized by two types of receptor, which are structurally and functionally different (see below).

Binding proteins and proteoglycans act both as carriers in biological fluids and as reservoirs of growth factors in the extracellular matrix (ECM) and at the cell surface, modulating bioavailability of their ligands. In the EGF family, heparin and heparan sulfate proteoglycans (HSPG) bind amphiregulin and heparin-binding EGF-like growth factor (HBEGF), but not EGF and TGF- $\alpha$ (Higashiyama ef al, 1993). In the FGF family, HSPG, by interacting with bFGF and aFGF, protects them from proteolytic cleavage and concentrates these factors in the pericellular space in the vicinity of the receptors. In addition, it was shown that bFGF and aFGF cannot bind their receptors or activate a cellular response unless heparin or HSPG molecules are present (Yayon et al., 1991). In the TGF- $\beta$ system, various types of binding compound are known. First, the latent TGF- $\beta$ binding protein (LTBP) binds the propeptide TGF- $\beta$ latency associated protein in a latent complex bound to the ECM (Taipale et al., 1994). Second, various other ECM compounds interact with TGF- $\beta$ and can mask or enhance the action of TGF- $\beta$. Among them, $\beta$-glycan, a cell-surface proteoglycan, can bind the mature form of TGF- $\beta$ and plays an important role in facilitating its interaction with the signalling receptors. In the IGF system, six specific binding proteins (IGFBPs) are known to bind IGFs with high affinity. Recent studies also suggest that IGFBPs on cell surfaces can play a local determinant role in modulating the bioavailability of IGFs for their receptors (see below).

To complete this rapid description of the growth factor systems, it is essential to mention also the proteases responsible for growth factor release by cleavage of precursors (TGF- $\alpha$, TGF- $\beta$ ), or by proteolysis of binding proteins (TGF- $\beta$, FGF, IGF). Additional studies are now necessary to identify these proteases and to assess how they are implicated in the modulation of growth factor bioavailability.

To understand the role of a growth factor in a physiological process like folliculogenesis, it is necessary to take into account all the elements of the system that is studied. The main questions are then the following: What is the origin (local, endocrine or both) of these elements in the ovary? Which elements are involved in the control of follicular development? How do these elements interact with gonadotrophins and other factors in the regulation of folliculogenesis? Our knowledge of the growth factor systems is too limited to answer all of these questions. In our laboratory, we are attempting to understand the role of the IGF system in sheep folliculogenesis, as a paradigm for the study of other growth factor systems.

\section{Role of the IGF System in Folliculogenesis}

As mentioned above, the IGF system is composed of different elements (Fig. I): two ligands (IGF-I and IGF-II), two receptors and six IGF-binding proteins.

The type I receptor mediates most of the somatomedin-like actions of both IGF-I and -II. It is a $\alpha 2, \beta 2$ tetramer structurally and functionally related to the insulin receptor. The affinity of this receptor for IGF-I is slightly higher than for IGF-II, and much higher than for insulin. However, the existence of insulin/IGF-I hybrid receptors, and of 'atypic' type I receptors leads to some frequent exceptions

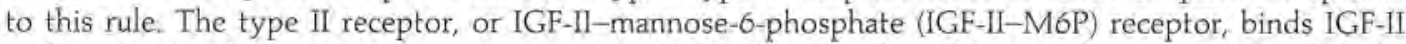
and molecules that possess a mannose-6-phosphate residue such as lysosomal enzymes and TGF- $\beta I$ (Nissley and Kiess, 1991). This receptor does not bind insulin, and binds IGF-I with very low affinity. It is therefore unlikely that IGF-II-M6P receptor mediates some IGF-I actions in vivo. An important function of type $\Pi$ receptor is to mediate the turnover of lysosomal enzymes. This receptor would also play a role in degradation of IGF-II after internalization (Nolan ef al., 1990), Moreover, experiments using IGF-II mutants have recently shown that the IGF-II-M6P receptor could mediate some unexpected actions of IGF-II, such as cell motility, but not 'classical' somatomedin-like actions such as mitogenesis. 


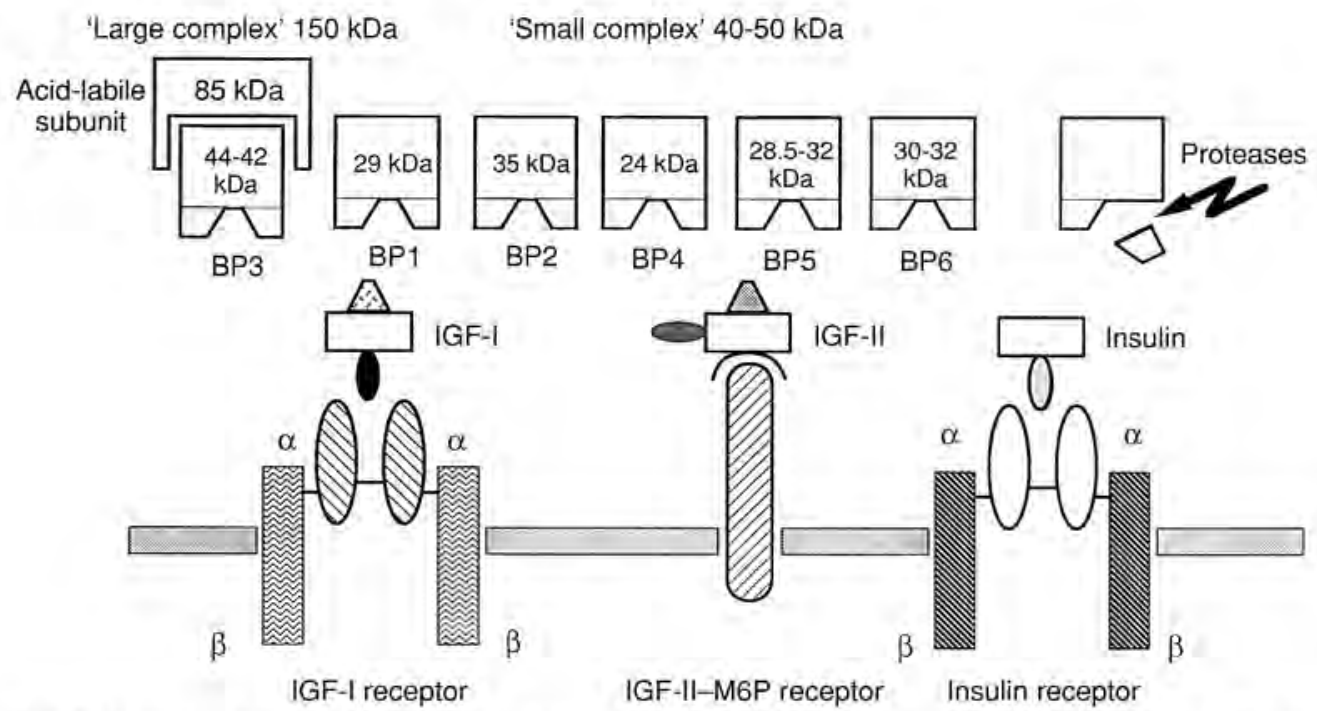

Fig, 1. Schematic representation of the IGF system. The IGF system is composed of IGF-1 and IGF-II, which are structurally related to insulin, two receptors (IGF-I receptor and IGF-II-M6P receptor), six binding

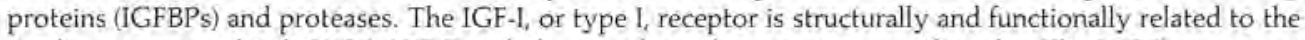
insulin receptor: it binds IGF-I, IGF-II and pharmacological concentrations of insulin. The IGF-II-mannose6-phosphate (IGF-II-M6P), or type II, receptor binds only IGF-II. The six IGFBPs (BPI to BP6) bind IGF-I and IGF-II, but not insulin. Proteases can degrade IGFBPs and decrease their affinity for IGFs.

The six IGF-binding proteins bind IGF-I and -Il with high affinity (Rechler, 1993). IGFBPs are present in all biological fluids. They can be arbitrarily classified into two groups.

IGFBP- $1,-2,-4,-5$ and -6 are present in serum and other fluids in the so called 'small complex'. When visualized by western-ligand blotting, their apparent molecular masses range between approximately $24 \mathrm{kDa}$ and $35 \mathrm{kDa}$. In this review, they will be called small molecular weight $1 \mathrm{GFBPs}$, or IGFBPs $<40 \mathrm{kDa}$. In serum, their concentrations are either negatively (IGFBP-1 and -2) or not regulated by growth hormone $(\mathrm{GH})$.

IGFBP-3 is the most predominant IGFBP in serum. In this fluid, it is mostly present in a $150 \mathrm{kDa}$ form ('large complex'), composed of IGF-I or IGF-II, and an acid-labile $85 \mathrm{kDa}$ subunit. Native IGFBP-3 is visualized as a $42-44 \mathrm{kDa}$ doublet by western-ligand blotting. The concentration of IGFBP-3 is positively regulated by $\mathrm{GH}$ and IGF-I.

IGFBPs, by increasing the half-life of IGFs, constitute a large pool of IGFs in all the compartments of the organism. Furthermore, IGFBPs can both inhibit and potentiate IGF action at target cells. They can inhibit IGF action by sequestration, since the affinity of IGFBPs for IGF-I and -II is of the same order of magnitude as the affinity of the type I receptor. However, the affinity of IGFBPs for IGF-I and -II can be modulated by post-transductional changes. In particular, the affinity of IGFBP-I for IGFs can be increased by phosphorylation as reported for human amniotic fluid at the end of pregnancy by Koistinen et al. (1993). Moreover, the affinity of IGFBPs for IGFs can be reduced when IGFBPs are bound to the ECM (IGFBP-5: Jones et al, 1993), or when they are proteolysed (IGFBP-3, IGFBP-5 and IGFBP-4). Such proteolysis was first described in the serum of female rodents and humans during pregnancy (Hossenlopp et al., 1990), after nutritional fasting, during severe illness or following severe trauma (Frost et al., 1993). Limited proteolysis of IGFBPs has also been described in serum and lymph of normal human adults (Lalou and Binoux, 1993), and in culture medium of osteoblastic cells, granulosa cells (Liu et al, 1993) and tumour cells (Frost et al., 1993). It is therefore highly likely that such a phenomenon occurs in vivo in most tissues. Moreover, it is important to note that this proteolysis can occur at the cell membrane (Conover, 1992). Such decreases in the affinity of IGFBPs for IGFs, by increasing bioavailability of IGFs, can lead to potentiation rather than inhibition of the action of the ligands. 


\section{Actions of IGF-I on follicular cells}

The actions of IGF-I on follicular cells are mediated on granulosa and thecal cells by type I receptors (reviewed by Adashi et al., 1992a and Giudice, 1992). Expression of this receptor in granulosa cells is increased by oestrogens and gonadotrophins in rats. In cows, expression of the IGF-I receptor increases in small antral follicles (Wandji et al., 1992). In sheep, no change in follicular IGF-I receptor concentrations was observed during growth of follicles from 0.8 to $8.0 \mathrm{~mm}$ diameter (Monget et al., 1989).

In sheep as in rats, pigs and humans, IGF-I stimulates both proliferation and differentiation of granulosa cells. IGF-I also stimulates steroidogenesis on thecal cells (reviewed by Adashi et al, 1992a and Giudice, 1992). Furthermore, in our laboratory we have clearly established that, in sheep, IGF-I stimulates mainly proliferation of granulosa cells from small follicles ( $1-3 \mathrm{~mm}$ diameter). By contrast, IGF-I stimulates secretion of progesterone by granulosa cells from large ( $>5 \mathrm{~mm}$ diameter), but not small, follicles (Fig. 2, Monniaux and Pisselet, 1992). It then seems that IGF-I stimulates either proliferation or differentiation of granulosa cells depending on the stage of development of the follicle.

Two non-exclusive hypotheses can be advanced to explain this phenomenon. First, other factors (such as growth factors and IGFBPs) may modulate the action of IGF-I in some way. For example, the presence of high concentrations of EGF (or TGF- $\alpha$ ) in small follicles (Hsu et al., 1987) may orientate IGF-I action towards stimulation of proliferation rather than differentiation. By contrast, the decrease in intrafollicular EGF concentrations (and possibly some changes in TGF- $\beta$ concentrations or bioavailability) in large follicles may allow the enhancement of cell differentiation in response to IGF-I. Second. the intrinsic capacity of granulosa cells to respond to IGF-I stimulation may change during growth of the follicle. We showed recently that in vitro, the percentage of proliferating cells was about $70 \%$ in granulosa cells from small follicles and less than 10\% in cells from large follicles (Monniaux et al., 1994). This difference in proliferation rate might be associated with a difference in intracellular concentrations of specific transcription factors. For example, c-jun is selectively expressed in mitotically active, but not in differentiating granulosa cells in rats (Delidow et al, 1992). Similarly in humans, c-myc was detected in granulosa from preantral rather than from large antral follicles ( $\mathrm{Li}$ et al, 1994). It can then be hypothesized that high concentrations of intracellular factors like c-jun and c-myc may promote proliferation rather than differentiation of granulosa cells in response to IGF-I.

In rats (Adashi et al., 1990), IGF-II seems to play similar roles to IGF-I in vitro; these actions are mediated by type 1 receptors.

\section{Changes in intrafollicular IGE-I and IGF-II concentrations during growth and atresia of ovarian follicles}

There is a heterogeneity in the localization of IGF expression in the ovary. In humans, IGF-I is expressed in thecal cells from small antral $(5-7 \mathrm{~mm}$ diameter) follicles, whereas IGF-II is highly expressed in granulosa cells from preovulatory follicles (El-Roeiy et al., 1993). By contrast, in rats, IGF-II is exclusively expressed in thecal cells (Hernandez et al., 1990), but IGF-I is expressed in granulosa cells from growing antral follicles (Zhou et al. 1991). In pigs. IGF-I mRNAs are found mainly in granulosa cells of growing antral follicles (Hammond et al., 1993). In humans (Voutilainen and Miller, 1987) and in pigs (Hatey et al., 1992), gonadotrophins stimulate synthesis of IGF-II and IGF-I by granulosa cells in vitro, respectively.

In follicular fluid, some authors have reported an absence of correlation between the size or stage of atresia of the follicles and their IGF-I concentrations (pigs: Veldhuis et al., 1986; cattle: Rutter and Manns, 1991; humans: Geisthovel et al., 1989; sheep; Monget et al, 1993), whereas others have found positive (pigs: Hammond et al., 1993) or negative correlations (pigs: Howard and Ford, 1992) between IGF-I concentrations and follicle size. Two main explanations can be proposed to explain the discrepancies between these results. First they may reflect interspecies differences in the localization of IGF synthesis in the ovary. Second, these discrepancies could be due to variations in the efficiency of the techniques of extraction of IGFBPs from small and large follicles (which contain different amounts of IGFBPs) before the IGF assays. Indeed some techniques have a poor efficacy of extraction, particularly concerning IGFBPs $<40 \mathrm{kDa}$ (Holly and Cwyfan Hughes, 1994). Hence, when such techniques are used, variations of IGFBP concentrations as high as observed between follicles of different sizes and qualities (see below) might probably not permit an accurate estimation of IGF concentrations in follicular fluid. 

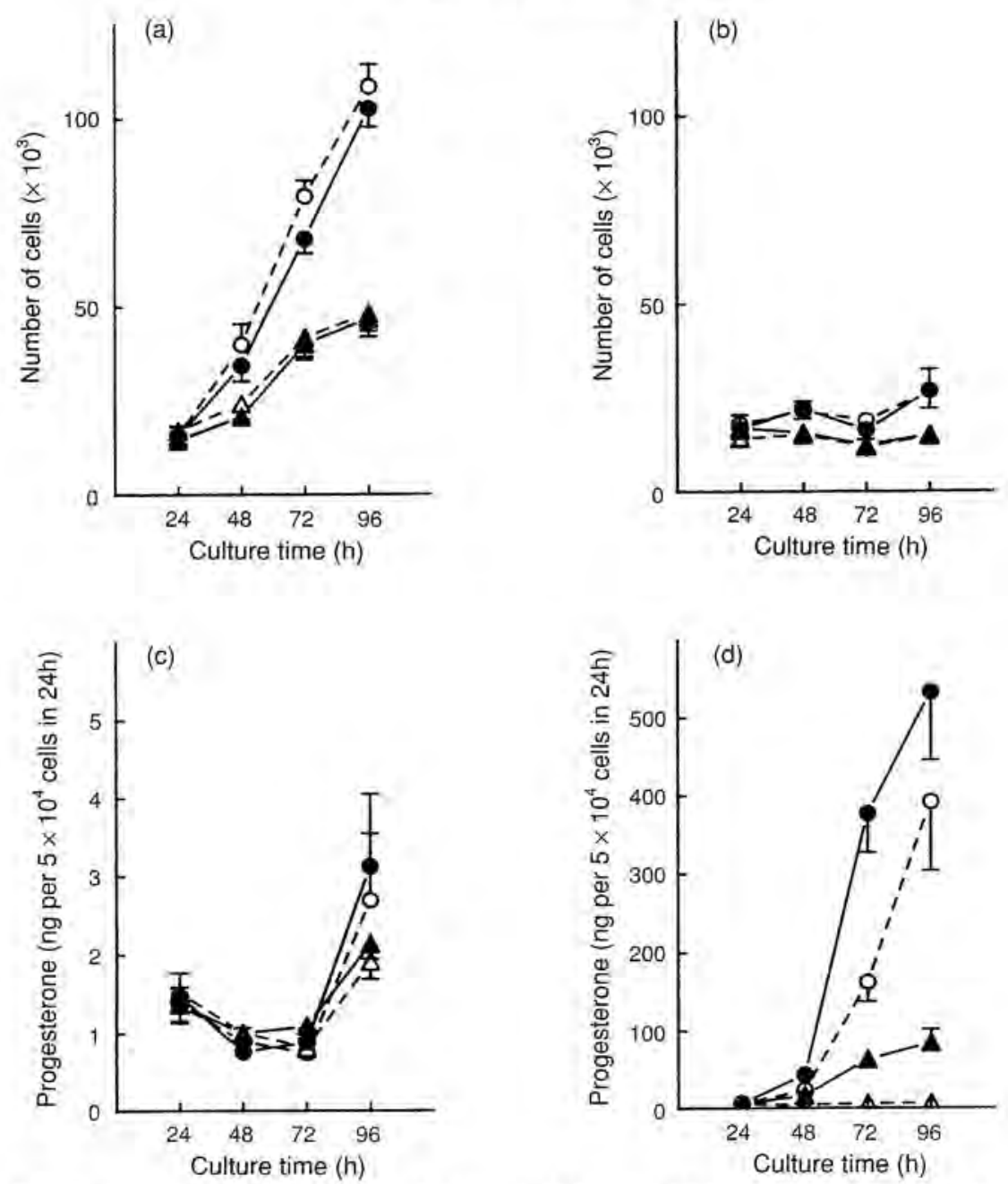

Fig, 2. Actions of insulin-like growth factor I (IGF-I) and FSH on ovine granulosa cells in vitro: (a) and (b) effects on proliferation and (c) and (d) progesterone synthesis. (a) and (c) Granulosa cells from small (1-3 mm diameter) (b) and (d) large (5-7 mm diameter) follicles were cultured for $96 \mathrm{~h}$ with and without FSH (100 $\left.\mathrm{ng} \mathrm{ml}^{-1}\right)$ in the presence or

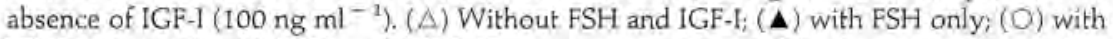
IGF-I only; (-) with FSH and IGF-I. Data represent (a) and (b) changes in the number of cells per culture well and (c) and (d) in the amount of progesterone secreted by granulosa cells with culture time. Redrawn from Monniaux et al. (1994) with permission of the Journal of Endocrinology Ltd.

Nevertheless, in all cases, the differences between IGF-I concentrations in the various classes of follicular fluid are small, and the follicular fluid IGF-I concentrations measured are always within the range of those shown to be effective in stimulating proliferation and steroidogenesis in granulosa cells in vitro. In fact, it seems that IGF bioavailability rather than IGF concentrations change markedly during growth and atresia of ovarian follicles (see below).

Finally, in women (Geisthovel et al., 1989), cows (Echternkamp et al., 1990), ewes (Monget et al., 1993) and mares (Spicer et al., 1991), the concentrations of IGF-I in large healthy follicles are positively. correlated with serum concentrations. In women, significant concentrations of IGF-I are found in 


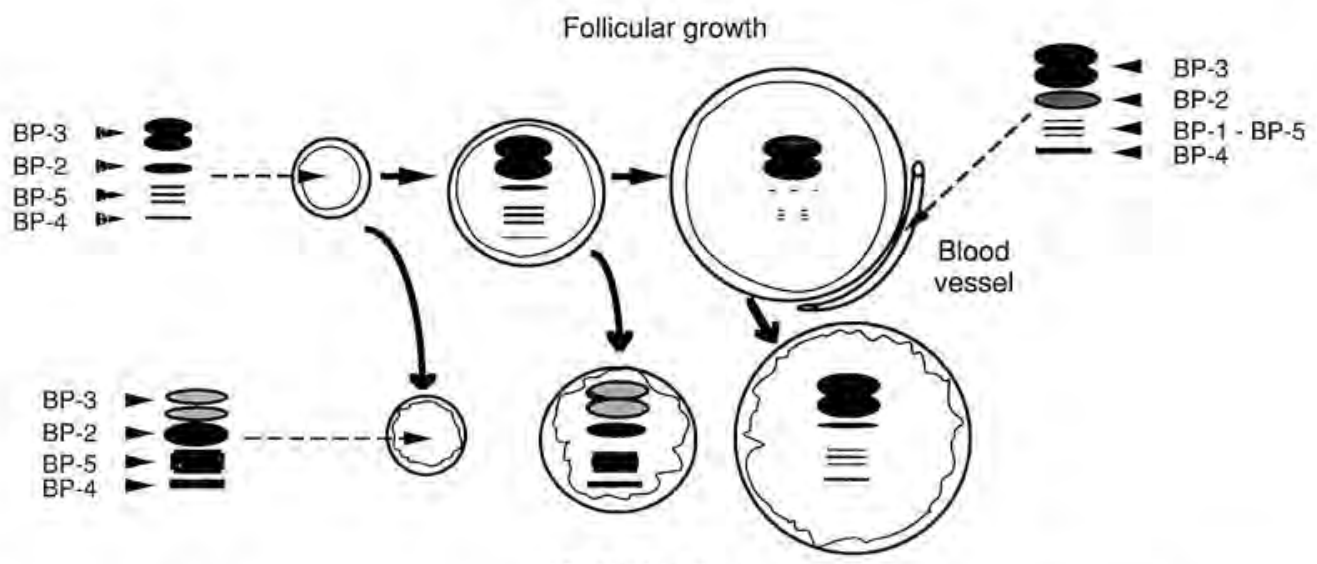

Follicular atresia

Fig. 3. Schematic representation of changes in intrafollicular insulin-like growth factor binding proteins (IGFBPs) during growth and atresia of anitral follicles in sheep. IGFBPs were assessed by western-ligand blotting on follicular fluid from follicles with various sizes $(2-8 \mathrm{~mm}$ diameter) and qualities. Follicular growth is characterized by a decrease and an increase in IGFBP-2, -4 and -5 (IGFBPs $<40 \mathrm{kDa}$ ) during follicular growth and atresia, respectively. Note that poorly vascularized small atretic follicles contain greater amounts of $1 \mathrm{GFBPs}<40 \mathrm{kDa}$ than does serum, whereas they cannot be detected in highly vascularized preovulatory follicles. IGFBP-3 increases slightly during follicular growth but decreases in small atretic follicles. IGFBP-I does not seem to be a major IGFBP in the ovary:

preovulatory follicles, whereas synthesis is very low. It is therefore possible that IGF-I in large normal follicles is derived, at least in part, from the circulatory pool in vivo.

\section{Changes in intrafollicular IGFBP concentrations during growth and atresia of ovarian follicles}

In sheep, analysis of follicular fluid by western-ligand blotting showed that follicular growth is accompanied by a slight increase in the intensity of the $42-44 \mathrm{kDa}$ IGFBP doublet, and clear decreases in those of the $35 \mathrm{kDa}$ and $24 \mathrm{kDa}$ bands; follicular atresia, by contrast, is accompanied by marked increases in the intensity of the 35, 28.5-32 and $24 \mathrm{kDa}$ bands (Fig. 3, Monget et al., 1993). The $35 \mathrm{kDa}$ and the $30 \mathrm{kDa}$ bands have been further identified by immunoblotting as ovine IGFBP- 2 and -5 , respectively. The $42-44 \mathrm{kDa}$ and $24 \mathrm{kDa}$ bands probably represent the ovine IGFBP-3 and -4 , respectively. In pigs, Mondschein et al. (1991) and Howard and Ford (1992) also showed an inverse relationship between the concentration of IGFBPs $<40 \mathrm{kDa}$ and the maturity of the follicle. In humans, intrafollicular IGFBP-2 and -4 concentrations are higher in atretic androgenic than in healthy oestrogenic follicles (Cataldo and Giudice, 1992). Hence, in these species, the increase in intrafollicular IGFBP-3: IGFBPs $<40 \mathrm{kDa}$ ratio appears to be strikingly associated with the growth and development of the follicle. The mechanisms that lead to such changes in intrafollicular IGFBP concentration are likely to be different for IGFBPs $<40 \mathrm{kDa}$ and IGFBP-3.

IGFBPs $<40 \mathrm{kDa}$. Several reports suggest that local paracrine processes are responsible for changes in small molecular weight IGFBPs during growth and atresia. First, in poorly vascularized, atretic follicles, the concentration of small molecular weight IGFBPs is higher in follicular fluid than in serum, suggesting some local synthesis. Moreover, from preliminary in situ hybridization experiments, atresia is characterized by a slight increase in IGFBP-4 expression in ovine thecal cells and a marked increase of IGFBP-5 expression in granulosa cells (authors' unpublished data). Similarly in the rat ovary, expression of IGFBP-4 and IGFBP-5 increases in granulosa cells of atretic follicles (Nakatani ef al., 1991; Erickson et al, 1992). 
Second, in pigs (Mondschein et al., 1991; Howard and Ford, 1992) and sheep (Monget et al., 1993), the concentration of IGFBPs $<40 \mathrm{kDa}$ progressively decreases in healthy growing follicles, and cannot be detected by western-ligand blotting in large highly vascularized preovulatory follicles, whereas significant concentrations are present in the corresponding serum. However, as serum proteins with molecular masses below $10^{3} \mathrm{kDa}$ can cross the basal membrane of the follicle (Shalgi et al., 1973), significant amounts of these IGFBPs should be found in follicular fluid of preovulatory follicles. Moreover, in sheep, in situ hybridization experiments have shown that IGFBP-2 is expressed in granulosa cells and IGFBP -4 and -5 are expressed in thecal cells from healthy ovine (particularly large) follicles (authors' unpublished data). El-Roeiy et al. (1994) found that, in women, IGFBP-2, -4 and -5 mRNAs are expressed in dominant follicles. What are the mechanisms that explain the absence of small molecular weight IGFBPs in follicular fluid from preovulatory follicles?

Inhibition of IGFBP expression by gonadotrophins in follicular cells would be one such mechanism. In sheep, preliminary in situ hybridization experiments show that expression of IGFBP-2 in granulosa cells of healthy follicles decreases during follicular growth (authors' unpublished data). Similarly in pigs, Samaras et al. (1993) showed a negative relationship between the concentrations of mRNAs encoding IGFBP-2 isolated from individual follicles and the diameter of these follicles or their concentration of progesterone. In rats, Liu et al. (1993) showed that expression of mRNAs encoding IGFBP-4 and -5 decreases in FSH-stimulated granulosa cells in vitro. Finally, in humans, Cataldo et al. (1993) showed that the secretion of IGFBP-2 by luteinizing granulosa cells in vitro is decreased by hCG and IGF-II.

Degradation of small molecular weight IGFBPs by specific intrafollicular proteases would be another mechanism. Liu et al. (1993) showed that FSH induces the production of a protease that degrades IGFBP-4 and -5 in rat granulosa cells in vitro.

Hence, in healthy growing follicles, gonadotrophins would not only reduce the expression of small molecular weight IGFBPs, but also induce the secretion of a protease(s) which would degrade locally synthesized as well as peripheral IGFBPs $<40 \mathrm{kDa}$, leading to an increase in the intrafollicular IGFBP-3:IGFBPs $<40 \mathrm{kDa}$ ratio. In atretic follicles, by contrast, an increase in the expression of IGFBPs $<40 \mathrm{kDa}$ and a putative decrease in the expression or activity of proteases would lead to a marked decrease in this ratio.

IGFBP-3. There is evidence for an endocrine origin (at least partly) of intrafollicular IGFBP-3. First, its concentration in preovulatory highly vascularized follicles is slightly lower (sheep: Monget et al., 1993) or quite similar (human: Cataldo and Giudice, 1992) to that in the corresponding serum as assessed by western-ligand blotting. Moreover, the systemic $150 \mathrm{kDa}$ IGFBP-IGF complex has been identified in ovine (Hodgkinson et al., 1989) and human (Kubota et al, 1993) follicular fluid. Furthermore, in rat (Nakatani et al., 1991) and pig (Samaras et al., 1992) ovaries, very low or no expression of IGFBP-3 was shown either in granulosa or thecal cells, unlike in the corpus luteum. Nevertheless, further experiments are necessary to elucidate the respective endocrine or paracrine roles of this IGFBP in the ovary.

Consequences of the bioavailability of IGFs at follicular cells. Previous studies have shown that IGFBP-4 and -5 inhibit both secretion of oestradiol and progesterone by FSH-stimulated rat granulosa cells in vitro (Liu et al., 1993). Such an inhibition could be explained by sequestration of endogenously produced IGFs. In our model, to understand the physiological consequences of the observed changes in IGFBP-3:IGFBPs $<40 \mathrm{kDa}$ ratio in ovine follicles further, we studied their relationship with intrafollicular free IGF binding activity. In ovine follicles, free IGF binding activity is positively correlated with concentrations of small molecular weight IGFBPs, and is higher in small than in large follicles, and in atretic than in normal follicles (Monget et al, 1993). These changes in free IGF binding activity may have important consequences for the bioavailability of IGFs at the granulosa cells. To assess this question, we studied the action of follicular fluid from healthy and atretic follicles on $\left[{ }^{3} \mathrm{H}\right]$ thymidine incorporation in ovine granulosa cells cultured with either IGF-I or its analogue [QAYL]-IGF-I, which has a weak affinity for IGFBPs. In the presence of $1 \%$ follicular fluid from healthy follicles, $1 \mathrm{ng}$ IGF-I ml ${ }^{-1}$ stimulates $\left[{ }^{3} \mathrm{H}\right]$ thymidine incorporation. By contrast, IGF-I action is inhibited in the presence of $1 \%$ follicular fluid from atretic follicles, whereas the action of the IGF-1 analogue remains unchanged, showing that the type 


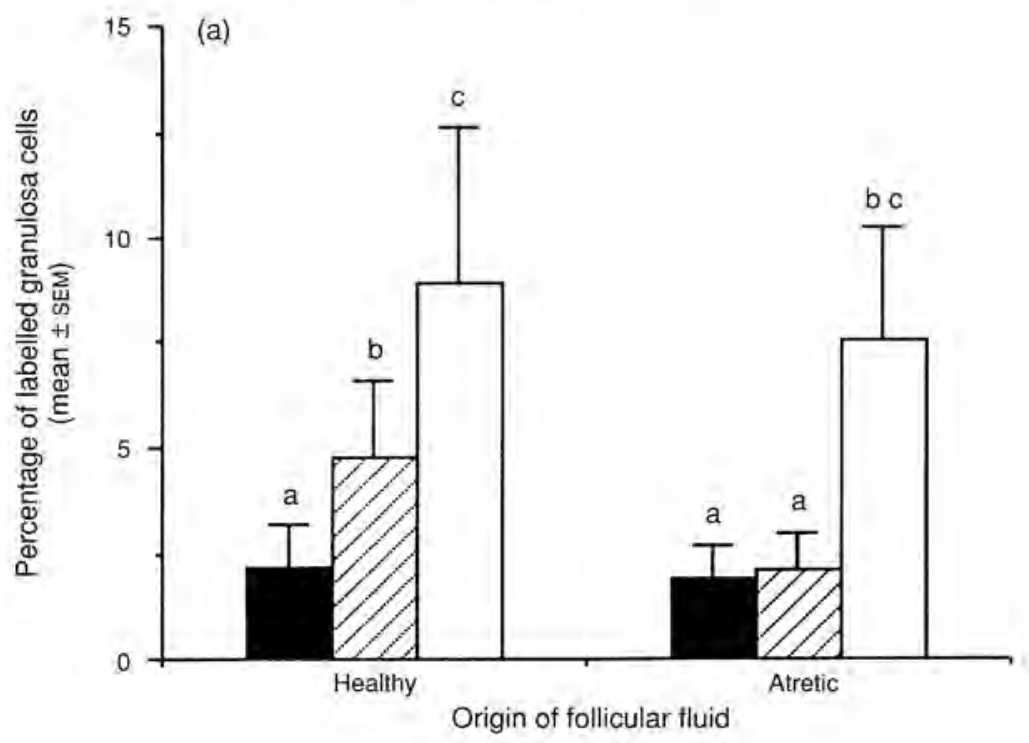

(b)

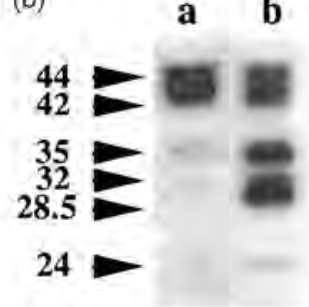

Fig. 4. (a) Effect of insulin-like growth factor I (IGF-I) and an IGF-I analogue on ovine granulosa cells in the presence of follicular fluid from healthy and atretic follicles. Granulosa cells from follicles of $1-3 \mathrm{~mm}$ diameter were cultured with $1 \%$ follicular fluid from either healthy or atretic follicles in the presence of IGF-I or an IGF-I analogue ([QAYL|IGF-I, which has a weak affinity for insulin-like growth factor binding proteins (IGFBPs)). ( Control; (ש) with IGF-I (1 $\mathrm{ng} \mathrm{ml}^{-1}$ ): (口) with IGF-I analogue $\left(1 \mathrm{ng} \mathrm{ml}^{-1}\right.$ ). After culture for $24 \mathrm{~h}$, cells were incubated with $0.25 \mu \mathrm{Ci}\left[{ }^{3} \mathrm{H}\right]$ thymidine $\mathrm{ml}^{-1}$ for $2 \mathrm{~h}$, and then treated for autoradiography. Data represent the percentage of labelled cells, estimated after analysis under a microscope. Columns with different letters are significantly different. (b) Patterns of IGFBPs of follicular fluid from healthy (lane a) and atretic (lane b) follicles used in these experiments were visualized by western-ligand blotting. Redrawn from Monget ef al. (1993) with permission, (1) The Endocrine Society.

of follicular fluid in the culture medium affects the action of IGF-I, but not of its analogue (Fig. 4). In similar experiments, Adashi et al. (1992b) showed that in vitro des(1-3)IGR-I, which has a weak affinity for IGFBPs, is more potent than IGF-I in promoting the FSH-stimulated accumulation of progesterone by rat granulosa cells in circumstances where IGFBPs are present, whereas both peptides are equipotent in circumstances in which IGFBPs are absent.

It should be noted that in the latter experiments, the role of IGFBPs in the action of IGFs was undertaken in vitro using soluble IGFBPs. In particular, it seems that soluble IGFBP-5 (present in follicular fluid) is a potent inhibitor of follicular growth. However, Jones et al. (1993) showed that IGFBP-5 can bind to laminin, fibronectin and type III and IV collagen. These authors suggested that the lower affinity of IGFBP- 5 bound to the ECM could serve as a reservoir of immobilized IGFs, facilitating delivery to type I receptor and then potentiating its action. In healthy ovine follicles, it is possible that IGFBP-5 
bound to ECM elements, such as laminin, fibronectin and collagen, enhances rather than inhibits IGF action on granulosa cells. This could also be the case for membrane-bound IGFBPs, particularly IGFBP-2 which binds to cell membranes by an RGD sequence peptide and, in that way, can enhance IGF-I action.

\section{Changes in type II receptor expression during growth and atresia of ovarian follicles}

Few data are available concerning the expression of type II receptors in the ovary. In sheep, its expression is closely related to the quality of the follicle, as it is expressed by thecal cells from healthy follicles and by granulosa cells from atretic follicles (Teissier et al., 1994). In humans by contrast, the type II receptor is highly expressed by granulosa cells from dominant follicles (El-Roeiy et al,, 1993). The role of this receptor in folliculogenesis is still unknown, and probably depends on the presence of its different ligands, IGF-II, lysosomal enzymes or TGF- $\beta$ I. However, a recent study strongly suggests that the IGF-II induced decrease in IGFBP-2 concentrations in luteinized human granulosa cell-conditioned medium is mediated by type II receptors (Cataldo et al, 1993). Hence in human preovulatory follicles, coexpression of high amounts of IGF-II and IGF-II-M6P receptors might contribute to the decrease in intrafollicular concentrations of IGFBP-2. However, further studies are necessary to confirm this hypothesis.

\section{Future Directions}

Ovarian folliculogenesis, like many biological functions, is controlled by apparently redundant systems of growth factors, most of them displaying quite similar functions on follicular cells: stimulation of proliferation (EGF, FGF, IGFs), stimulation of differentiation (IGF-I, TGF- $\beta$ ) or inhibition of differentiation (EGF, FGF, TNF- $\alpha$ ). Within each system, the many ligands and receptors that have discrete and overlapping functions also lead to functional redundancy: for example, IGF-I and -II, or TGF- $\alpha$ and EGF, seem to display the same functions in the ovary. Natural genetic mutations have provided some information about the role of some of these growth factors. For example, in mice, the Steel and the c-kit mutations lead to a complete absence of germinal cells in the ovary (as well as in the testis), providing evidence for their crucial role in oogenesis. Moreover, the production of transgenic mice by targeted disruption of genes will provide information on the exact roles of these factors on folliculogenesis. TGF- $\alpha$, for example, does not seem to be indispensable for ovarian physiology, since transgenic mice lacking these factors are fertile (Luetteke ef al., 1993). The knock-out of the IGF-II gene also does not alter fertility of mice (DeChiara et al., 1991), whereas mice lacking IGF-I are infertile (Baker et al., 1993). However, in this case, it is difficult to conclude definitively on the direct role of IGF-I in the ovary, since such a targeted disruption also affects extraovarian compartments such as pituitary FSH/LH cells or hypothalamic GnRH neurones. Moreover, extrapolation of these results to other species requires some caution. In humans, the Laron syndrome is characterized by a general resistance to $\mathrm{GH}$ action and by a great decrease in IGF-I concentrations in serum and follicular fluid, but follicular growth appears quite normal, and women are fertile (Dor et al., 1992).

Moreover, biological effects of growth factors in the ovary depend on many different parameters. First, as suggested above for IGFs, the stage of differentiation of follicular cells (which depends itself on the action of gonadotrophins and other growth factors), and then the set of transcription factors present in the nucleus, may orientate the response to a growth factor. In the same way, TGF- $\beta$ exerts pleiotropic effects on follicular cells and the cellular response to TGF- $\beta$ is probably determined by the concentration or activity of intracellular transcription factors. In particular, as suggested by results obtained on Chinese hamster ovary cells (Bissonnette et al., 1992), it is possible that the increase in c-myc expression in granulosa cells following stimulation by a mitogenic factor, such as IGF-I or EGF, could respectively increase proliferation rate, or induce apoptosis and follicular atresia, depending on the amount of survival factors such as bcl-2 in the cells. It was reported that c-myc is expressed in both highly proliferative and degenerating granulosa cells (Li et al., 1994). Among transcription factors, intracellular steroid receptors may also influence the action of growth factors. In particular, the mitogenic action of IGF-I and EGF on human breast cancer cells is partly mediated by oestradiol receptors (Chalbos et al., 1993). In the same way, we have shown that in vilro, in steroid-free culture conditions, the mitogenic action of IGF-I on 
ovine granulosa cells is partly inhibited by ICI164-364, a specific inhibitor of the oestradiol receptor (M. Tomanek, C. Pisselet and D. Monniaux, unpublished). The mechanisms of action of growth factor transducing signals on these intracellular transcription factors remain to be investigated in the ovary.

Finally, biological actions of growth factors critically depend on their bioavailability in the vicinity of the cell. Bioavailability is determined by the concentration of ligands, by the concentrations of their binding proteins and by the ability of specific proteases to degrade binding proteins or to cleave latent forms of growth factors. It is the 'fine tuned' combination of these different parameters which determines the window of concentration allowing growth factors to trigger a specific cellular response. For example, overexpression of the proteoglycan syndecan in transfected fibroblasts causes downregulation of bFGF-induced cell proliferation (Mali ef al., 1993). In the ovary, there is an abundance of HSPG in degenerating follicles (Bushmeyer et al., 1985 and authors' unpublished observations). It can be hypothesized that, as locally produced IGFBPs in atretic follicles inhibit IGF action, the increased expression of HSPG in degenerating follicles might inhibit FGF action on follicular cells. Moreover, modulation of extracellular bFGF action in the ovary might depend less on its level of expression (which is low) than on the action of proteoglycanases which modulate its bioavailability. It is now crucial to study the involvement of all the elements that can modulate bioavailability of growth factors in the ovary.

It is also important to determine the exact role of growth factors in the mediation of gonadotrophin actions on follicular growth and atresia. In vitro, in serum-free culture conditions, IGFBP-4 and -5 (Liu et al., 1993) inhibit FSH-induced steroidogenesis on rat granulosa cells, suggesting a determinant role for endogenous IGF-I in the mechanism of action of FSH. The inhibition of FSH-induced DNA synthesis of hamster follicles in vitro by addition of a specific antibody against EGF (Roy and Greenwald, 1991), strongly supports the contention that this factor plays a critical role in the mediation of gonadotrophininduced follicular growth. Furthermore, growth factors may also be implicated in LH-induced follicular atresia of small antral follicles during the follicular phase. McNeilly et al. (1992) suggested that, in sheep, selection of preovulatory follicles during the follicular phase involves a decrease in FSH concentrations and an increase in LH pulse frequency. Such an increase in the LH:FSH ratio would enhance growth of dominant follicles which express LH receptors in thecal and granulosa cells, but induce atresia of smaller antral follicles, devoid of LH receptors in granulosa cells. As TGF- $\alpha$ is expressed mainly in thecal cells from small antral follicles in cows, and putatively in ewes, it is possible that, as suggested by McNeilly et al. (1992), theca-derived TGF- $\alpha$ would partly mediate the LH-induced atresia on small antral follicles, by inhibiting terminal differentiation. Further experiments are necessary to investigate whether, during the follicular phase, an increase in the LH:FSH ratio would also play an active role in increasing the expression of IGFBPs $<40 \mathrm{kDa}$ in small non-ovulatory follicles.

\section{Conclusion}

To study the role of a growth factor in folliculogenesis, it is necessary to integrate all the elements of the system to which it belongs: the growth factors, their receptors, their binding proteins and proteases that may alter the bioavailability of the ligands. The IGF system is considered as a paradigm for the study of the action of growth factors in the ovary since most of its elements (except proteases) are identified. In sheep, as in most mammals, terminal follicular growth is characterized mainly by a marked decrease in intrafollicular concentrations of IGFBPs $<40 \mathrm{kDa}$ (IGFBP-2, -4 and -5 ). This decrease is responsible for an increase in bioavailability of IGFs, leading to an amplification of the action of gonadotrophins in preovulatory follicles. By contrast, atresia is characterized by a marked increase in intrafollicular IGFBPs $<40 \mathrm{kDa}$ concentrations and in inhibition of the action of IGFs.

\section{References}

Adashi EY, Resnick CE and Rosenfeld RG (1990) Insulin-like growth factor-I (IGF-I) and IGF-II hormonal action in cultured granulosa cells: mediation via type 1 but not type II IGF receptors Endocrinology $126754-760$
Adashi EY, Resnick CE, Hurwitz A Ricciarelli E, Hernandez ER, Roberts CT, LeRoith D and Rosenfeld RG (1992a) The intra-ovarian IGF system Growth Regulation 2 $10-15$ 
Adashi EY, Resnick CE, Ricciarelli E, Hurwitz A, Kokia E, Tedeshi C, Botero L, Hernandez ER, Rosenfeld RG, Carlsson-Skwirut C and Francis GL (1992b) Granulosa cellderived insulin-like growth factor (IGF) binding proteins are inhibitory to IGF-1 homonal action Joumal of Clinical Investigation 90 1593-1599

Attisano L, Carcamo J, Ventura F, Weis JMB, Massagué J and Wrana JL (1993) Identification of human activin and TGE- $\beta$ type I receptors that form heteromeric kinase complexes with type II receptors Cell 75 671-680

Baker J. Liu J-P, Robertson EJ and Efstratiadis A (1993) Role of insulin-like growth factors in embryonic and postnatal growth Cell 75 73-82

Bissonnette RP, Echeverri F, Mahboubi A and Green DR (1992) Apoptotic cell death induced by c-myc is inhibited by bcl-2 Nature $359552-555$

Bushmeyer SM, Bellin ME, Brantmeier SA, Boehm SK, Kubajak CL and Ax RL. (1985) Relationships between bovine follicular fluid glycosaminoglycans and steroids Endocrinology 117 879-885

Cataldo NA and Guidice LC (1992) Insulin-like growth factor binding protein profiles in human ovarian follicular fluid correlate with follicular functional status Journal of Clinical Endocrinology and Metabolistn 74 821-829

Cataldo N, Woodruff TK and Giudice LC (1993) Regulation of insulin-like growth factor binding protein production by human lutemizing granulosa cells cultured in defined medium Journal of Clinical Endocrinology and Metabolism 76 207-215

Chalbos D, Philips A, Galtier F and Rochefort H (1993) Synthetic antiestrogens modulate induction of $\mathrm{pS} 2$ and cathepsin-D messenger ribonucleic acid by growth factors and adenosine $3^{\prime}, 5^{\prime}$-monophosphate in MCF7 cells Endocrinology 133 571-576

Conover CA (1992) Potentiation of insulin-like growth factor (IGF) action by IGF-binding protein-3: studies of underlying mechanism Endocrinology 130 3191-3199

DeChiara TM, Robertson EJ and Efstratiadis A (1991) Parental imprinting of the mouse insulin-like growth factor II gene Cell 64 849-859

Delidow BC, Lynch JP, White BA and Peluso JJ (1992) Regulation of proto-oncogene expression and deoxyribonucleic acid synthesis in granulosa cells of perifused immature rat ovaries Biology of Reproduction $47428-435$

Dor J, Ben-Shlomo I, Lunenfeld B, Pariente C, Levran D, Karasik A, Seppälä M and Mashiach S (1992) Insulin-like growth factor-I (IGF-1) may not be essential for ovarian follicular development: evidence from IGF-I deficiency Journal of Clinical Endocrinology and Metabolism 74 539-542

Echternkamp SE, Spicer LJ, Gregory KE, Canning SF and Hammond JM (1990) Concentrations of insulin-like growth factor-1 in blood and ovarian follicular fluid of cattle selected for twins Biology of Reproduction 43 8-14

El-Roeiy A, Chen X, Roberts V], LeRoith D, Roberts CT, Jr and Yen SSC (1993) Expression of insulin-like growth factor-1 (IGF-I) and IGF-II and the IGF-I, IGF-II, and insulin receptor genes and localization of the gene products in the human ovary Joumal of Clinical Endocrinology and Metsbolism 77 $1411-1418$

El-Roeiy A, Chen X, Roberts VJ, Shimasaki S, Ling N, LeRoith D, Roberts CT, Jr and Yen SSC (1994) Expression of the genes encoding the insulin-like growth factors (IGF-I and -II), the IGF and insulin receptors, and IGF-binding proteins-1-6 and the localization of their gene products in normal and polycystic ovary syndrome ovaries Journul of Clinical Endocrinology and Metabolism $78 \quad 1488-1496$

Erickson GF, Nakatani A, Ling $N$ and Shimasaki S (1992) Localization of insulin-like growth factor-binding protein-5 messenger ribonucleic acid in rat ovaries during the estrous cycle Endocrinology $130 \quad 1867-1878$

Frost VJ, Macaulay VM, Wass JAH and Holly JMP (1993) Proteolytic modification of insulin-like growth factor-binding proteins: comparison of conditioned media from human cell lines, circulating proteases and characterized enzymes Jounal of Endocrinology 138 545-554

Geisthovel F, Moretti-Rojas IM, Rojas FJ and Asch RH (1989) Immunoreactive insulin-like growth factor 1 in human folliculat fluid Human Reproduction 4 35-38

Giudice IC (1992) Insulin-like growth factors and ovarian follicular development Endocrine Revienos 13 641-669

Hammond JM, Samaras SE, Grimes R, Leighton J, Barber J, Canning SF and Guthrie HD (1993) The role of insulin-like growth factors and epidermal growth factor related peptides in intraovarian regulation in the pig ovary Journal of Reproduction and Ferfility Supplement 48 117-125

Hatey F, Langlois I, Mulsant P. Bonnet A, Benne F and Gasser F (1992) Gonadotropins induce accumulation of insulin-like growth factor I mRNA in pig granulosa cells in vitro Molecular and Cellular Endocrinology 86 205-211

Hernandez ER, Roberts CT, Jr, Hurwitz A, LeRoith D and Adashi EY (1990) Rat ovarian IGF-II gene expression is theca-interstitial cell-specific: hormonal regulation and receptor distribution Endocrinology $1273219-3226$

Higashiyama S, Abraham JA and Klagsbrun M (1993) Heparinbinding EGF-like growth factor stimulation of smooth muscle cell migration: dependence on interactions with cell surface heparan sulfate Joumal of Cell Biology 122 933-940

Hodgkinson SC, Moore L. Napier JR, Davis SR, Bass JJ and Gluckman PD (1989) Characterization of insulin-like growth factor binding proteins in ovine tissue fluids Journal of Endocrinology 120 429-438

Holly JMP and Cwyfan Hughes SC (1994) Measuring insulinlike growth factors: why, where and how? Joumal of Endocrinolog! 140 165-169

Hossenlopp P, Segovia B, Lassarre C, Roghani M, Bredon M and Binoux M (1990) Evidence of enzymatic degradation of insulin-like growth factor binding proteins in the $150 \mathrm{~K}$ complex during pregnancy Journal of Clinical Endocrinology and Metabolism 71 797-805

Howard HJ and Ford JJ (1992) Relationship among concentrations of steroids, inhibin, insulin-like growth factor-1 (IGF-I), and IGF-binding proteins during follicular development in weaned sows Biology of Reproduction 47 193-201

Hsu CJ, Holmes SD and Hammond JM (1987) Ovarian epidermal growth factor-like activity concentrations in porcine follicular fluid during follicular enlargement Biochenvical and Biophysical Research Communications 147 242-247

Jones J, Gockerman A, Busby WH, Jr, Camacho-Hubner C and Clemmons D (1993) Extracellular matrix contains insulinlike growth factor binding protein-5: potentiation of the effects of IGF-1 The Journal of Cell Biology 121 679-687

Koistinen R, Angèrvo M, Leinonen P, Hakala T and Seppälä M (1993) Phosphorylation of insulin-like growth factorbinding protein- I increases in human amniotic fluid and decidua from early to late pregnancy Clinica Chinica Acta 215 189-199 
Kubota T, Sakamoto S, Kamada S, Shimizu Y, Ohara M, Aso T and Tagushi M (1993) Insulin-like growth factor II in follicular fluid of the patients with in vitro fertilization and embryo transfer Fertility and Sterility 59 844-849

Lalou C and Binoux M (1993) Evidence that limited proteolysis of insulin-like growth factor binding protein-3 (IGFBP-3) occurs in the normal state outside of the bloodstream Regulatony Pephides 48 179-188

Li S, Maruo T, Ladines-Llave CA, Kondo H and Mochizuki M (1994) Stage-limited expression of myc oncoprotein in the human ovary during follicular growth, regression and atresia Endocrine Joumal $41 \quad 83-92$

Liu X-J, Malkowski M, Guo Y, Erickson GF, Shimasaki S and Ling N (1993) Development of specific antibodies to rat insulin-like growth factor-binding proteins (IGFBP-2 to -6): analysis of IGFBP production by rat granulosa cells Endocrinology $1321176-1183$

Logan A (1990) Commentary: intracrine regulation at the nucleus - a further mechanism of growth factor activity? Joumal of Endocrinology 125 339-343

Luetteke NC, Qiu TH, Peiffer RL, Oliver P, Smithies O and Lee DC (1993) TGF alpha deficiency results in hair follicle and eye abnormalities in targeted and waved-1 mice Cell 73 263-268

McNeilly AS, Crow W, Brooks J and Evans G (1992) Luteinizing hormone pulses, follide-stimulating hormone and control of follicle selection in sheep Journal of Reproduction and Fertility Supplement 45 5-19

Mali M, Elenius K, Miettinen HM and Jalkanen M (1993) Inhibition of basic fibroblast growth factor-induced growth promotion by overexpression of syndecan-1 Joumal of Biological Chemistry $268 \quad 24215-24222$

Mondschein JS, Etherton TD and Hammond JM (1991) Characterization of insulin-like growth factor binding proteins of porcine ovarian follicular fluid Biology of Reproduction 44 $315-320$

Monget P, Moruiaux D and Durand P (1989) Localization, characterization and quantification of insulin-like growth factor-I-binding sites in the ewe ovary Endocrinology 125 2486-2493

Monget P, Monniaux D, Pisselet C and Durand P (1993) Changes in insulin-like growth factor-1 (IGF-1), IGF-Il, and their binding proteins during growth and atresia of ovine ovarian follicles. Endocrinology 132 1438-1446

Monniaux D and Pisselet C (1992) Control of proliferation and differentiation of ovine granulosa cells by insulin-like growth factor-1 and follicle-stimulating hormone in vitro Biology of Reproduclion 46 109-119

Monniaux D. Pisselet C and Fontaine J (1994) Uncoupling between proliferation and differentiation of ovine granulosa cells in vilto Journal of Endocrinology 142 497-510

Nakatani A, Shimasaki S, Erickson GF and Ling N (1991) Tissuc-specific expression of four insulin-like growth factor-binding proteins $(1,2,3$, and 4$)$ in the rat ovary Endocrinology 129 1521-1529

Nissley SP and Kiess W (1991) Binding of insulin-like growth factor-II (IGF-II) and lysosomal enzymes to the IGF-1I/ mannose-6-phosphate receptor. In Modem Concepts of Insulin-like Grotwh Fatciors pp 419-430 Ed. EM Spencer. Elsevier Science Publishers, New York

Nolan CM, Kyle JW, Watanabe H and Sly WS (1990) Binding of insulin-like growth factor II (IGF-II) by human cationdependent mannose 6-phosphate receptor/IGF-II receptor expressed in receptor-deficient mouse L cells Cell Regulation 1 $197-213$
Rechler MM (1993) Insulin-like growth factor binding proteins Vitamins and Hormones 47 1-114

Roy SK and Greenwald GS (1991) Mediation of folliclestimulating hormone action on follicular deoxyribonucleic acid synthesis by epidermal growth factor Endocrinology 129 1903-1908

Rutter LM and Manns JG (1991) Jnsulin-like growth factor I in follicular development and function in postpartum beef cows Journal of Animal Science 69 1140-1146

Samaras SE, Hagen DR, Shimasaki S, Ling N and Hammond JM (1992) Expression of insulin-like growth factor-binding protein- 2 and -3 messenger ribonucleic acid in the porcine ovary: localization and physiological changes Endocrinology $1302739-2744$

Samaras SE, Guthrie HD, Barber JA and Hammond JM (1993) Expression of the mRNAs for the insulin-like growth factors and their binding proteins during development of porcine ovarian follicles Endocrinology 133 2395-2398

Shalgi R, Kraicer P, Rimon A, Pinto M and Soferman N (1973) Proteins of human follicular fluid: the blood-follicle barrier Ferrility and Sterility 24 429-434

Spicer LJ, Tucker KE, Henderson KA and Duby RT (1991) Concentrations of insulin-like growth factor-! in follicular fluid and blood plasma of mares during early and late oestrus Animal Reproduction Science 25 57-65

Taipale J, Miyazono K, Heldin CH and Keski-Oja J (1994) Latent transforming growth factor- $\beta 1$ associates to fibroblast extracellular matrix via latent TGF- $\beta$ binding protein Jountal of Cell Biology 124 171-181

Teissier MP, Monget P, Monniaux D and Durand P (1994) Changes in insulin-like growth factor-II/mannose-6phosphate receptor during growth and atresia of ovine ovarian follicles Biology of Reproduction 50 11 I-119

Turnbull JE and Gallagher JT (1993) Heparan sulphate: functional role as a modulator of fibroblast growth factor activity Biochemical Society Transactions 21 477-482

Veldhuis J. Rodgers RJ and Furlanetto RW (1986) Synergistic actions of estradiol and the insulintike growth factor, somatomedin-C, on swine ovarian (granulosa) cells Endocrinology 119 530-538

Voutilainen R and Miller WL (1987) Coordinate tropic hormone regulation of mRNAs for insulin-like growth factor II and the cholesterol side-chain-cleavage enzyme, P450ssc, in human steroidogenic tissues Proceedings of the National Acadeny of Sciences of the USA 84 1590-1594

Wandji SA. Pelletier G and Sirard MA (1992) Ontogeny and cellular localization of ${ }^{125}$-labeled insulin-like growth factor-I, ${ }^{125} \mathrm{I}$-labeled follicle-stimulating hormone, and ${ }^{125} \mathrm{I}$ labeled human chorionic gonadotropin binding sites in ovaries from bovine fetuses and neonatal calves Biology of Reproduction 47 814-822.

Wong ST, Winchell LF, McCune BK, Earp HS, Teixido J, Massagué J, Herman B and Lee DC (1989) The TGFprecursor expressed on the cell surface binds to the EGF receptor on adjacent cells leading to signal transduction Cell 56 495-506

Yayon A, Klagsbrun M, Esko JD, Leder P and Ornitz DM (1991) Cell surface, heparin-like molecules are required for binding of basic fibroblast growth factor to its high affinity receptor Cell $84 \quad 841-848$

Zhou J, Chin E and Bondy C (1991) Cellular pattern of insulinlike growth factor-f (IGF-1) and IGF-1 receptor gene expression in the developing and mature ovarian follicle Endocrinology 129 3281-3288. 